\title{
AMENDMENTS
}

\section{Author Correction: The blue carbon wealth of nations}

\section{Christine Bertram, Martin Quaas (D), Thorsten B. H. Reusch (D), Athanasios T. Vafeidis (1), Claudia Wolff(D) and} Wilfried Rickels (D)

Correction to: Nature Climate Change https://doi.org/10.1038/s41558-021-01089-4, published online 12 July 2021

In the version of this Article initially published, in the first sentence of the second paragraph of the section titled "Blue carbon wealth redistribution," there was an error. In the sentence reading: "The five donor countries that generate the largest blue carbon wealth surpluses are, in addition to Australia: Indonesia, Cuba, Russia and Papua New Guinea," the country Papua New Guinea should instead have read as "Guinea-Bissau."

The error has been corrected in the online version of this article.

\begin{abstract}
(c) (i) Open Access This article is licensed under a Creative Commons Attribution 4.0 International License, which permits use, sharing, adaptation, distribution and reproduction in any medium or format, as long as you give appropriate credit to the original author(s) and the source, provide a link to the Creative Commons license, and indicate if changes were made. The images or other third party material in this article are included in the article's Creative Commons license, unless indicated otherwise in a credit line to the material. If material is not included in the article's Creative Commons license and your intended use is not permitted by statutory regulation or exceeds the permitted use, you will need to obtain permission directly from the copyright holder. To view a copy of this license, visit http://creativecommons.org/ licenses/by/4.0/.
\end{abstract}

Published online: 3 September 2021

https://doi.org/10.1038/s41558-021-01172-W

(c) The Author(s) 2021

\section{Publisher Correction: Climate mitigation through Indigenous forest management}

Alyssa Findlay

Correction to: Nature Climate Change https://doi.org/10.1038/s41558-021-01042-5, published online 6 May 2021.

In the version of this Q\&A originally published, the surname of the interviewee Paul Redman was spelt incorrectly as 'Redmond'. This has now been corrected in the online versions of the Q\&A.

Published online: 4 June 2021

https://doi.org/10.1038/s41558-021-01088-5

(c) Springer Nature Limited 2021 